\title{
Patch-Clamp Evidence for Calcium Channels in Apical Membranes of Rabbit Kidney Connecting Tubules
}

\author{
Sally Tan and Kai Lau \\ Section of Nephrology, Department of Medicine, University of Oklahoma and Department of Veterans Affairs Medical Center, \\ Oklahoma City, Oklahoma 73104
}

\begin{abstract}
To test the hypothesis that $\mathrm{Ca}$ channel plays a role in renal epithelial Ca transport, we exposed and patched apical membranes of freshly microdissected rabbit connecting tubules (CNTs). Single channel Ca currents were recorded with Ba as the charge carrier. In the cell-attached mode, 8-Br-cAMP increased the open-state probability $\left(P_{0}\right)$ to $0.6 \%$. In excised, inside-out patches, $P_{0}$ was low spontaneously and remained low during either bath protein kinase $A$ catalytic subunit $\left(\mathbf{P K} \mathbf{A}_{\mathrm{cs}}\right)$ or Bay K 8644. Exposure to both agonists, however, unmasked Ca channels previously latent with only one, raising $\boldsymbol{P}_{0}$ by $1.05 \%$ at membrane potential of $-70 \mathrm{mV}$.

Mean $\boldsymbol{P}_{\mathrm{o}}$ for 14 seals $(2.57 \%)$ peaked at $-70 \mathrm{mV}$, declining with either hyperpolarization or depolarization. The slope conductance was $25 \mathrm{pS}$. The extrapolated reversal potential (138 $\mathrm{mV}$ ) agrees with the calculated equilibrium potential for $\mathrm{Ca}$ $(158 \mathrm{mV})$. The $\mathrm{Ca}$ to $\mathrm{Na}$ permeability ratio exceeded 2,800 . In four patches stimulated by Bay $K 8644$ and $P K A_{c s}$, bath nifedipine reduced $P_{0}$ from 1.03 to $0.15 \%$ at $-63 \mathrm{mV}$. These patchclamp data demonstrate a selective, 25-pS, cAMP/PK $\mathbf{A}_{\mathrm{cs}}$-sensitive Ca channel in apical membranes of CNT. $P_{0}$ is stimulated by $P K A_{c s}$ and dihydropyridine (DHP) agonist, but inhibited by DHP antagonist and by depolarization. The data are consistent with the potential role of apical membrane Ca channel in epithelial Ca transport. (J. Clin. Invest. 1993. 92:2731-2736.) Key words: apical membrane $\bullet$ calcium • channels • patch-clamp • tubules
\end{abstract}

\section{Introduction}

Earlier studies indicate that PTH and cAMP stimulate Ca transport in rabbit kidney connecting tubules $(\mathrm{CNT})^{1}(1,2)$. Our recent fura- 2 studies suggest that $\mathrm{PTH}$ and $\mathrm{CAMP}$ both increase $\mathrm{Ca}$ entry across the apical membrane $(\mathrm{AM})(3,4)$. Together, these results raise the hypothesis that apical membrane $\mathrm{Ca}$ channels are the initial and PTH-regulated step in lumen-tobath $\mathrm{Ca}$ transport. However, to date, there exists no direct or

Address reprint requests to Dr. Kai Lau, Room 2E109, VA Hospital and Medical Center, 921 N.E. 13th Street (111G), Oklahoma City, OK 73104. 1993.

Received for publication 28 August 1992 and in revised form 28 July

1. Abbreviations used in this paper: AM, apical membrane; BLM, basolateral membrane; $\mathrm{CNT}$, connecting tubule; $E_{\text {eq }}$, equilibrium potential; $E_{\text {rev }}$, reversal potential; $P_{\mathrm{o}}$, open-state probability; $\mathrm{PD}$, potential difference; $\mathrm{PKA}_{\mathrm{cs}}$, protein kinase A catalytic subunit; PKC, protein kinase $C ; V_{\mathrm{m}}$, membrane potential; $V_{\mathrm{p}}$, pipette potential.

The Journal of Clinical Investigation, Inc.

Volume 92, December 1993, 2731-2736 definitive evidence other than changes in $\left[\mathrm{Ca}^{2+}\right]_{i}$ consistent with the expected response to dihydropyridine (5) and/or PTH (3-5). But PTH also activates basolateral membrane (BLM) Ca influx (3), a process reproducible by cAMP (4) and suppressible by protein kinase A (PKA) inhibitors (6). Thus, whole-cell $\left[\mathrm{Ca}^{2+}\right]_{i}$ response does not necessarily identify the specific site of actions in a polarized epithelial cell, let alone defining the pathway as an apical Ca channel.

Recently, the techniques of tubule dissection, lumen exposure, and patch-clamp electrophysiology have been combined to fruitfully study AM Na and $\mathrm{K}$ channels in cortical collecting tubules $(7,8)$. We used a similar strategy to test the Ca channel hypothesis in the rabbit CNT. Our results are herein reported.

\section{Methods}

Albino rabbits were fed regular laboratory diet until they weighed $\geq 1.9$ $\mathrm{kg}$. After decapitation, CNTs were dissected as before $(3,4,6)$, at $10^{\circ} \mathrm{C}$ in a solution containing (in $\mathrm{mM}$ ) $\mathrm{KCl} 5, \mathrm{NaCl} 148, \mathrm{CaCl}_{2} 1.7$, $\mathrm{Na}_{2} \mathrm{HPO}_{4} 2, \mathrm{MgCl}_{2}$ 1.2, D-glucose 5.6, L-alanine 6, and $\mathrm{pH}$ to 7.4 with $\mathrm{NaOH}$. Placed on a $0.5-\mathrm{cm}^{2}$ plastic plate and following the method of Palmer and Frindt (7), the CNT was split lengthwise to expose the AM and immobilized by tacking down at both ends. The plate was transferred into a superfusion chamber $(0.35 \mathrm{ml})$ over an inverted microscope. Separate power supply and grounding were used to minimize noise. All patch-clamp equipment was housed, if possible, inside an aluminum Faraday cage on a vibration-free table. Direct current battery illuminated the microscope. Till excision, the CNT was bathed in a solution containing (in $\mathrm{mM}$ ) $\mathrm{Na}$ acetate $138, \mathrm{~K}$ acetate $5, \mathrm{Mg}$ acetate 1.5, Ca acetate 1.8 , Hepes 10 , D-glucose 5 , and pH to 7.4 with $\mathrm{NaOH}$. Patch electrodes, 8-10 M $\Omega$, made from capillary tubes by a two-stage vertical puller (Narashige USA, Greenvale, NY), were filled with a solution containing (in $\mathrm{mM}$ ) Ba acetate 50 , Ca acetate 0 or 1.8, D-mannitol 143-148, and in some experiments, amiloride $0.2 \mathrm{mM}$ and/or Bay K 8644. Mounted on the integrated head stage of an Axopatch 1-D amplifier (Axon Instruments, Inc., Foster City, CA ), the electrode was lowered into the bath. After offsetting liquid junction potential, the electrode was deposited on the AM to establish a high resistance seal ( $\geq 15 \mathrm{G} \Omega$ ) by gentle suction. Both on-cell and excised, inside-out patches were studied at $22 \pm 1^{\circ} \mathrm{C}$. After excision, bath contained 0 or 20 $\mathrm{mM} \mathrm{Na}$ acetate, 0.23 or $0.5 \mathrm{mM} \mathrm{Mg}$ acetate, $10 \mu \mathrm{M}$ EGTA, and enough D-mannitol (231-273 mM) to match the osmolality of pipette solution. The $0.23 \mathrm{mM} \mathrm{Mg}$ bath was used to accommodate the extra free $\mathrm{Mg}$ due to $2 \mathrm{mM} \mathrm{Mg} \mathrm{ATP}$. CsOH was used to adjust $\mathrm{pH}$ of $\mathrm{Na}$-free solutions to 7.4. Cations leaving pipette were recorded as upward deflections on line to a personal computer interfaced with analog to digital/digital to analog converter at a $500-\mu$ s rate and filtered at $2 \mathrm{kHz}$. Currents were also stored in a videocassette recorder (Toshiba, Elmont, NY) via a digital recorder. Data were analyzed by pCLAMP software program (Axon Instruments, Inc.) at $2 \mathrm{kHz}$ by a computer digital Gaussian filter. A channel was considered open if duration $\geq 500 \mu \mathrm{S}$ and amplitude $\geq i_{0}+\left(i_{1}-i_{0}\right) / 2$, where $i_{0}$ denoted closed state and $i_{1}$ open-state currents. $P_{\mathrm{o}}$ is calculated as the ratio of fractional open time to the maximal number of unitary current amplitudes in a given seal recorded $\geq 20 \mathrm{~min}$. Fractional open time, derived by the pCLAMP software, is defined as the sum total of time duration of all open events divided by the total recording time. 
All reagent-grade chemicals were obtained from Sigma Chemical Co. (St. Louis, MO) except for: nifedipine, Bay K 8644, and Hepes (Ultra grade) from Calbiochem Corp. (La Jolla, CA); fura-2 free acid from Molecular Probes Inc. (Eugene, OR), $\mathrm{CsOH}$ from Aldrich Chemical Co. (Milwaukee, WI). The composition and osmolality of all solutions were verified by published methods $(3,4,6)$. Data were subjected to appropriate Student's $t$ tests (9) and presented as mean \pm SE. A $P$ value $\geq 0.05$ is considered significant.

\section{Results}

For pipette potentials $\left(V_{\mathrm{p}}\right)$ between -10 and $70 \mathrm{mV}$, spontaneous $P_{\mathrm{o}}$ for cell-attached patches was $0.026 \pm 0.023 \%(n=7)$. Activity was very infrequent in the absence of agonists. $11.5 \pm 2.3 \mathrm{~min}$ after incubation with bath 8-Br-cAMP, 1-3.75 $\mathrm{mM}$, channel recordings were resumed in the continued presence of cAMP. The midpoint of this cAMP period corresponded to $17.8 \pm 2.2 \mathrm{~min}$ after introducing $8-\mathrm{Br}$-cAMP to the bath. Mean $P_{\mathrm{o}}$ was raised to $0.54 \pm 0.13 \%$, with an increment of $0.51 \pm 0.15, P<0.02$ (Fig. 1, top). From the current-voltage relationship (Fig. 1, bottom), the slope conductance was calculated to be $24.2 \mathrm{pS}$ and the extrapolated pipette reversal potential $\left(E_{\mathrm{rev}}\right)$ was $-188 \mathrm{mV}$. Since distal tubule AM is known to be depolarized $\sim 42 \mathrm{mV}$ by lumen $\mathrm{Ba}$ (from -70 to $-28 \mathrm{mV}$ ) (10), this $E_{\text {rev }}$ corresponds to a transmembrane potential difference (PD) of $160 \mathrm{mV}[-28-(-188)]$. Thus, the PD is comparable to the calculated Nernst equilibrium potential $\left(E_{\mathrm{eq}}\right)$ of $162 \mathrm{mV}$.

To better define the time course of cAMP action, recordings were made at 2,4 , and 6 min after administration of $8-\mathrm{Br}$ cAMP in four of these seven cell-attached patches. No stimulation was detectable at an applied $V_{\mathrm{p}}$ of 0 or $55 \mathrm{mV}$ during the initial 2 and 4 min after 8-Br-cAMP. However, further monitoring at $V_{\mathrm{p}}$ of $0,25-30$, or $55 \mathrm{mV}$, revealed significant effects on $P_{\mathrm{o}}$ by the 6 th min of cAMP exposure $(0.60 \pm 0.17 \%)$ (Fig. 2 ). Subsequent recordings at 10-11-min intervals pulsed at similar $V_{\mathrm{p}}$ demonstrated sustained and similar action during the 11 th $\min (0.50 \%), 22$ nd $\min (0.46 \%), 33$ rd $\min (0.85 \%)$, 43rd $\min (0.78 \%)$, 53rd $\min (0.40 \%)$, and 93rd min $(0.40 \%)$ of 8 -Br-cAMP treatment. These results suggest that at the latest, significant and full effects of 8-Br-cAMP are demonstrable between 5 and $7 \mathrm{~min}$ after bath administration, resembling the time course of stimulation of $\left[\mathrm{Ca}^{2+}\right]_{i}$ in the CNT $(3,4,6)$. Strictly speaking, it is not possible to vigorously compare these two effects of 8-Br-cAMP because of several technical and intrinsic biological reasons. First, by definition, the apical membrane patch clamp approach precludes the contribution of $\mathrm{Ca}$ influx across the basolateral membrane, which is known to be a definite and major source for the rise in $\left[\mathrm{Ca}^{2+}\right]_{\mathrm{i}}$ as revealed by prior epifluorescence studies (4). Second, the change in fura-2 signals represents the total summation of all $\mathrm{Ca}$ influxed across a number of cells in a $0.3-0.5-\mathrm{mm}$ length of CNT continually monitored, as opposed to the periodic measurements of ion current across $1 \mu \mathrm{m}$ of apical membrane pulsed at intervals. Third, in our previous epifluorescence studies, the chamber temperature was $37^{\circ} \mathrm{C}$, as opposed to $22^{\circ} \mathrm{C}$ in the present patch-clamp experiments. Fourth, the sensitivity limits may be quite different between these two vastly different experimental techniques.

In the cell-attached mode, cytosolic conditions facing the interior of the patched membrane cannot be defined or controlled. To control cytoplasmic solution composition and membrane potential $\left(V_{\mathrm{m}}\right)$, subsequent studies were therefore done in excised, inside-out patches. Before excision, an 82-s

\section{Before}
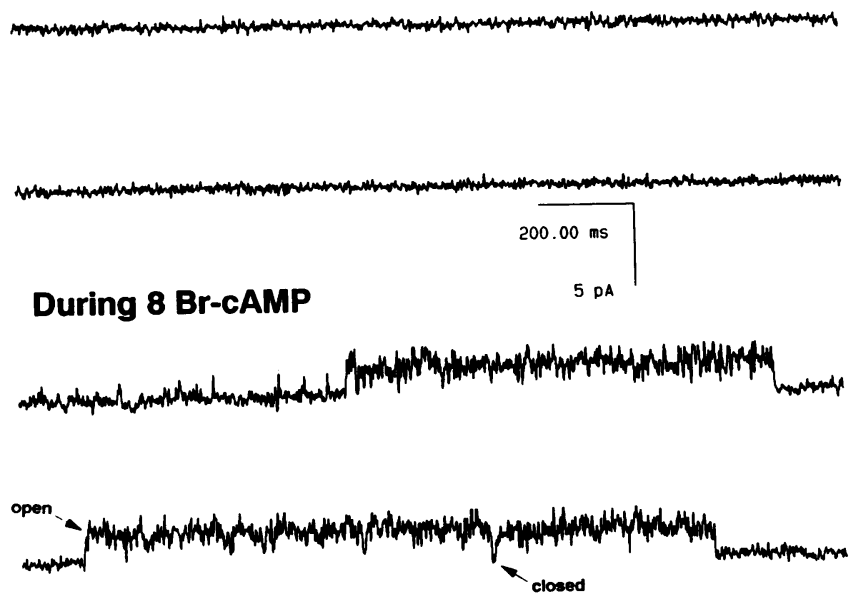

Current (pA)

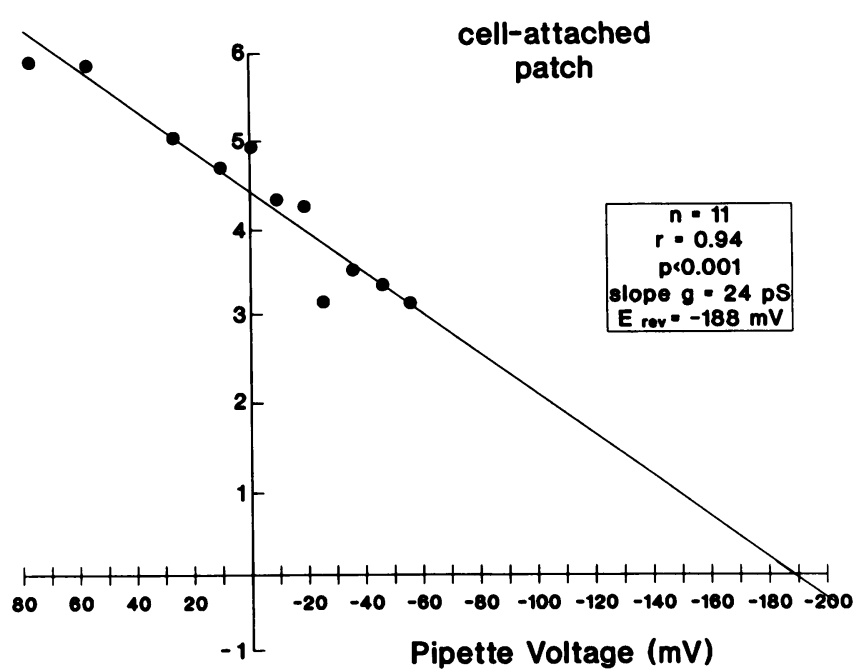

Figure 1. (Top) Response of a cell-attached patch before (upper two tracings) and during $1 \mathrm{mM}$ 8-Br-cAMP (lower two tracings). Pipette contained $0.2 \mathrm{mM}$ amiloride. $V_{\mathrm{p}}=55 \mathrm{mV}$. Channel closure is indicated by "closed." (Bottom) Corresponding current-voltage curve.

record was made at zero $V_{\mathrm{p}}$, although generally no electrical activity was found.

In excised patches, spontaneous activity was absent in all but 1 seal $\left(P_{\mathrm{o}}=0.052 \%\right.$ at $\left.-60 \mathrm{mV}\right)$, under the conditions of our experiment. Overall, 36 of 60 excised patches displayed $\mathrm{Ca}$ channel if stimulated by agonists. Five seals were relatively quiet at $-70 \mathrm{mV}$, with only bath Bay $\mathrm{K}, 20 \pm 8 \mu \mathrm{M}\left(P_{\mathrm{o}}\right.$ $=0.068 \pm 0.057 \%)$. When $\mathrm{PKA}_{\mathrm{cs}}$ was added to the bath, $P_{\mathrm{o}}$ became $1.25 \pm 0.75 \%$ (Fig. 3 ). Conversely, three seals were relatively quiet at $-70 \mathrm{mV}$, with $P_{\mathrm{o}}$ of $0.006 \%$ when exposed to only $1 \mu \mathrm{g} / \mathrm{ml}$ of bath PKA $A_{c s}$ and $2 \mathrm{mM}$ of Mg ATP until Bay K was added $\left(P_{\mathrm{o}}=0.83 \pm 0.53 \%\right)$ (Fig. 4$)$. The response of these eight seals, negative with only one agonist but positive with dual agonists $\left(P_{\mathrm{o}}=1.09 \pm 0.45, P<0.05\right)$, suggests cooperativity. On the average, 2.3 channels were found per patch (mean tip diameter, $1 \mu \mathrm{m}$ ). A single channel recorded for over $20 \mathrm{~min}$ with unambiguous unitary current is shown in Fig. 5.

14 seals, all treated with $\mathrm{PKA}_{\mathrm{cs}}$ and Bay $\mathrm{K}$, were subjected to various test potentials (Fig. 6). $P_{\mathrm{o}}(2.57 \%$ ) peaked at -70 $\mathrm{mV}$, the estimated resting $V_{\mathrm{m}}$ for apical membranes of CNT 


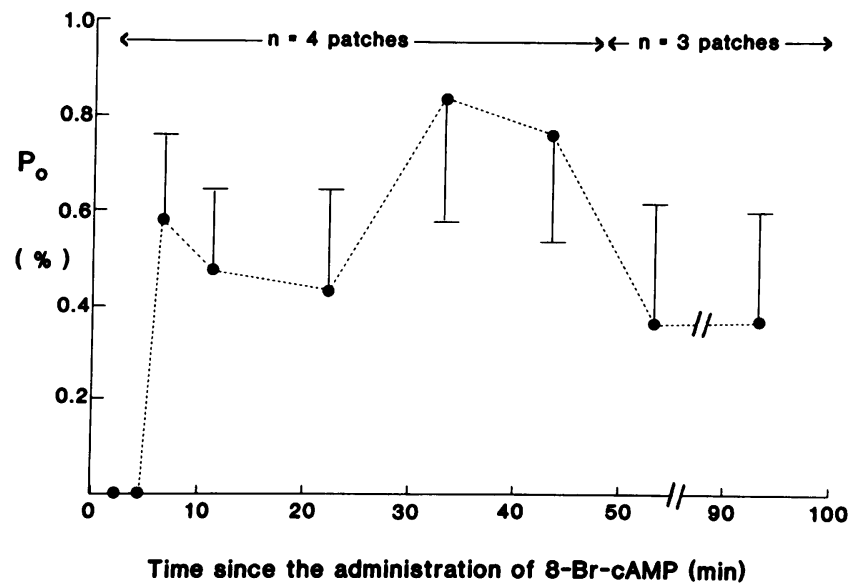

Figure 2. Time course of the stimulatory effects of 8-Br-cAMP on $\mathrm{P}_{\mathrm{o}}$ of apical $\mathrm{Ca}$ channels in four cell-attached patches. Recordings were made at 2, 4, and $6 \mathrm{~min}$ after introducing $1-3.75 \mathrm{mM}$ 8-Br-cAMP into the bath and repeated at $11,23,33,63,53$, and $93 \mathrm{~min} . V_{\mathrm{p}}$ was 0,25 or 30 , and $55 \mathrm{mV}$ at each time point.

(11), declining to $0.57 \%$ at $-50 \mathrm{mV}$ and to $<0.3 \%$ as the $V_{\mathrm{m}}$ deviated from the resting value. Depolarization beyond -20 $\mathrm{mV}$ essentially abolished all openings, which were restored by repolarization.

Peak current was plotted against $V_{\mathrm{m}}$ for 12 inside-out patches (Fig. 7). $E_{\mathrm{eq}}$ was calculated by the Goldman equation. Pipette $\mathrm{Ba}^{2+}(50 \mathrm{mM})$ and $\mathrm{Ca}^{2+}(1.8 \mathrm{mM})$ were assumed to be $100 \%$ dissociated, based on the measured osmolality. Bath $\left[\mathrm{Ca}^{2+}\right]$, buffered by $10 \mu \mathrm{M}$ EGTA, was $200 \mathrm{nM}$, as analyzed by fluorometric titration with fura- 2 free acid. The calculated $E_{\mathrm{eq}}$ was $158 \mathrm{mV}$, in good agreement with the $E_{\text {rev }}$ extrapolated from the current-voltage curve $(138 \mathrm{mV})$ (Fig. 7), although more vigorous determinations of $E_{\text {rev }}$ will depend on additional data obtained over $V_{\mathrm{m}}$ in the more positive range. In contrast, the calculated $E_{\text {eq }}$ for $\mathrm{Na}$ was $34.9 \mathrm{mV}$, using pipette [Na] of $80 \mu \mathrm{M}$ and bath [ $\mathrm{Na}$ ] of $20 \mu \mathrm{M}$, as measured by atomic absorptionmetry from four bath aliquots. In eight seals, pipette contained $0.2 \mathrm{mM}$ amiloride and bath [Na] was $20 \mathrm{mM}$. The calculated $\mathrm{Na} E_{\text {eq }}$ was $-139 \mathrm{mV}$. The current-voltage curve for these eight seals yielded similar results $(r=0.93, P<0.01$, slope $g=26 \mathrm{pS}$, and $E_{\mathrm{rev}}=132 \mathrm{mV}$ ). Calculated as published (12), the $\mathrm{Ca} / \mathrm{Na}$ permeability ratio was 2,855 , indicating a high selectivity of this channel for $\mathrm{Ca}$ over $\mathrm{Na}$.

Effects of nifedipine, $25 \mu \mathrm{M}$ to $1 \mathrm{mM}$, were studied in four seals (Fig. 8). Before excision, CNTs were incubated in 3.75 $\mathrm{mM} 8$-Br-cAMP for $21 \pm 5 \mathrm{~min}$. Pipette contained $24 \pm 10 \mu \mathrm{M}$ Bay $\mathrm{K}$ throughout all phases of the experiments. After excision, bath contained $1 \mu \mathrm{g} / \mathrm{ml} \mathrm{PKA}_{\mathrm{cs}}, 2 \mathrm{mM} \mathrm{Mg} \mathrm{ATP}$, and $\leq 0.05 \%$ DMSO. In two seals, bath also contained $50 \mu \mathrm{M}$ Bay $\mathrm{K}$, but this additional source of Bay $\mathrm{K}$ produced similar results. These agonists raised peak $P_{\mathrm{o}}$ to $1.03 \pm 0.12 \%$. When nifedipine was added to the bath with identical [ $\mathrm{PKA}_{\mathrm{cs}}$ ] and [ $\mathrm{Mg} \mathrm{ATP}$ ], replacing any previous bath BAY K, $P_{\mathrm{o}}$ fell by $0.88 \pm 0.09 \%$ to $0.15 \pm 0.10 \%, P<0.005$, despite the continued presence of pipette Bay $K$ and bath PKA $A_{c s}$ (Fig. 8). In two seals studied, substitution of bath nifedipine with bath Bay $\mathrm{K}$ restored channel activity.

\section{Discussion}

Our data document $\mathrm{Ca}$ channels in apical membranes of rabbit $\mathrm{CNT}$, with a $60 \%$ incidence. With $50 \mathrm{mM} \mathrm{Ba}$, the slope $g$ is 25
Bay K 8644

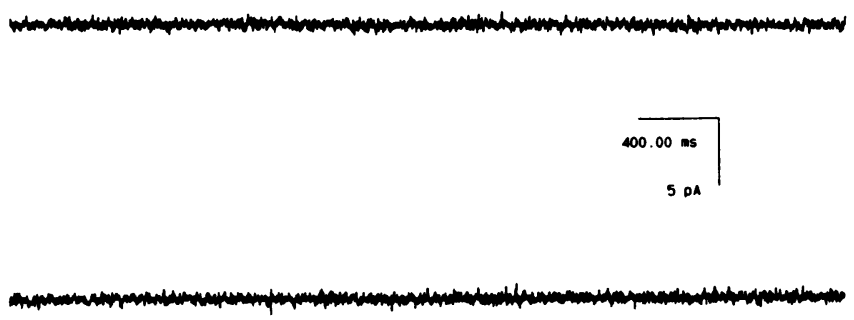

\section{Bay K 8644 \& PKA cs}
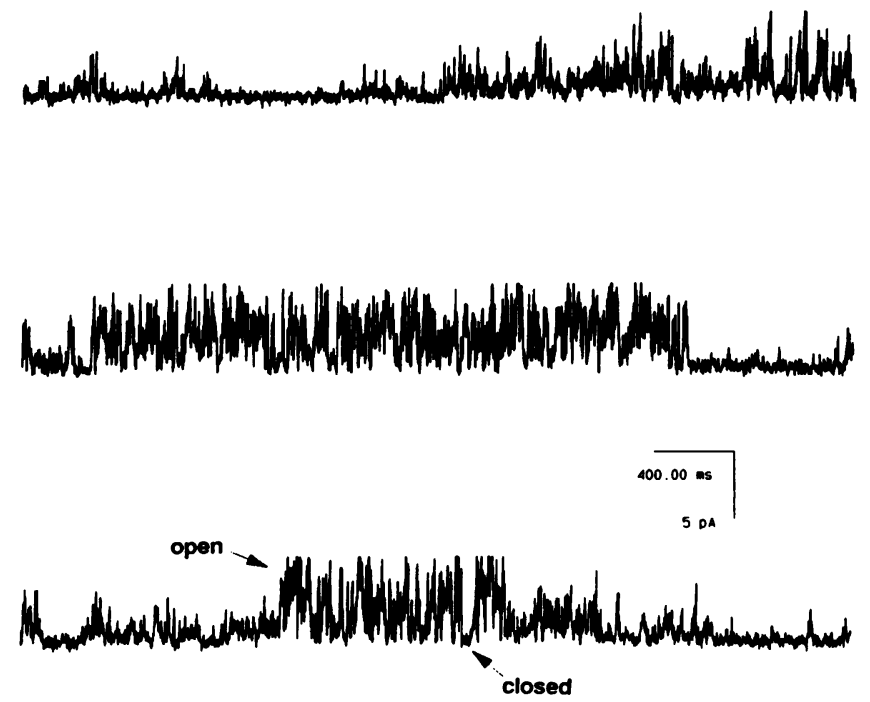

Figure 3. Effect of bath $\mathrm{PKA}_{\mathrm{cs}}(1 \mu \mathrm{g} / \mathrm{ml})$ and $\mathrm{Mg} \mathrm{ATP}(2 \mathrm{mM})$ in an excised, inside-out seal pretreated with $18.5 \mu \mathrm{M}$ bath Bay K 8644 . $V_{\mathrm{m}}=-90 \mathrm{mV}$. Upper two tracings, Bay $\mathrm{K}$ alone; bottom three tracings, during Bay $\mathrm{K}$ and $\mathrm{PKA}_{\mathrm{cs}}$. Baseline current levels are denoted as closed. These tracings are representative of five similar seals.

pS. Ca/Na permeability ratio was $\sim 2,800$. Spontaneous $P_{\mathrm{o}}$ is negligible, but it is stimulated to $\sim 2 \%$ by agonists. The channels are activated by either cAMP/PK A cs $_{\text {or }}$ DHP Ca agonist, with the most consistent stimulation if exposed to both. Channel activity is reversibly inhibited by dihydropyridine $\mathrm{Ca}$ antagonist. These features are shared by voltage-activated L-type Ca channels in excitable tissues (12-15).

There are, however, notable differences. First, renal cell $\mathrm{Ca}$ channels are not activated by membrane depolarization (Fig. 6 ), which largely though reversibly abolished all openings. Activity seemed to peak around $-70 \mathrm{mV}$, the reported resting $V_{\mathrm{m}}$ (10). Second, the run-down phenomenon found in excitable cells $(11,13,14)$ is absent in cell-free membrane patches of CNT if treated with PKA $A_{c s}$ and ATP.

Several inferences can be made from our results. First, the patch clamp data are consistent with the notion that the PTHactivated, cAMP-stimulated apical membrane $\mathrm{Ca}$ influx step is a Ca channel. Second, between the BLM and AM across which PTH and cAMP enhance Ca entry $(3,4)$, our data suggest the $\mathrm{AM}$ as at least one target site, also consistent with the known stimulation of transepithelial $\mathrm{Ca}$ absorption. Third, the precise cellular mechanism(s) for PTH action have been controversial, given the evidence separately for the second messenger role of 
PKA CS

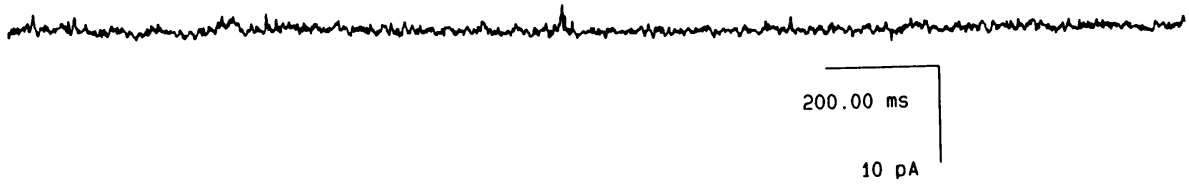

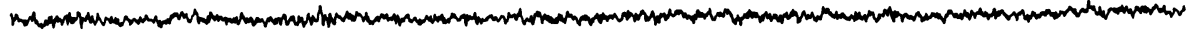

Bay K 8644 \& PKA cs

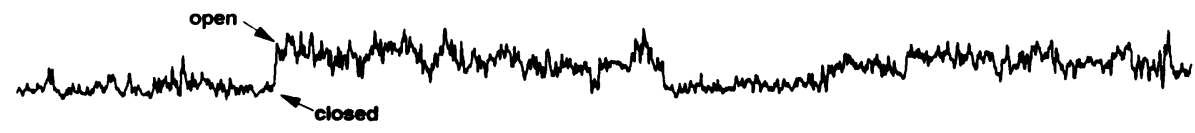

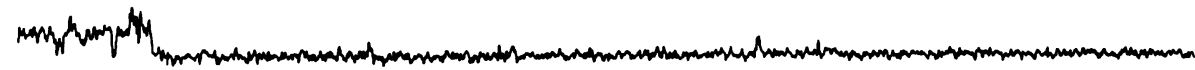

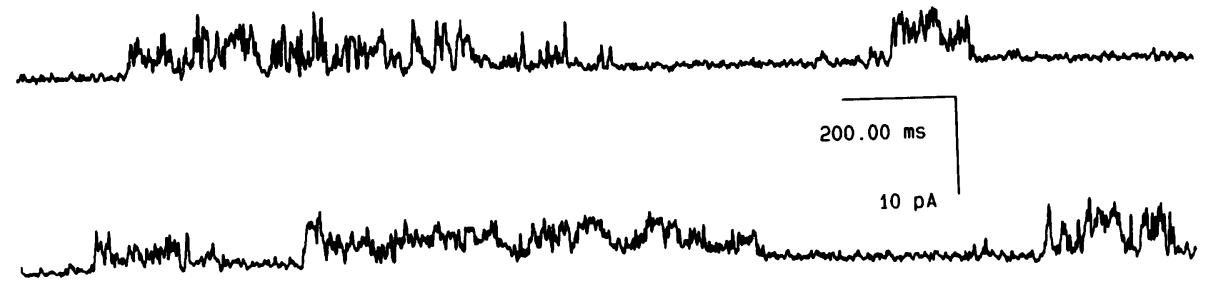

Figure 4. Effects of bath Bay K 8644 $(50 \mu \mathrm{M})$ in an excised, inside-out patch pretreated with $18.5 \mu \mathrm{M}$ pipette Bay $\mathrm{K}$ $(1 \mu \mathrm{g} / \mathrm{ml}$ of PKA $\mathrm{cs}$ and $2 \mathrm{mM} \mathrm{Mg}$ ATP). $V_{\mathrm{m}}=-70 \mathrm{mV}$. Baseline current levels are denoted as closed. This tracing is representative of three similar patches.
diacylglycerol-PKC (16), inositol 1,3,4 trisphosphate (16) and PKA (6). For example, in intact tubules, reproduction by cAMP of the stimulatory effects of PTH on $\left[\mathrm{Ca}^{2+}\right]_{i}$ could be due to increased luminal $\mathrm{Na}$ entry and consequently enhanced BLM Ca influx via the $\mathrm{Ca}: \mathrm{Na}$ antiporter. Likewise, the suppression of these effects by nonspecific protein kinase inhibitors (6) does not exclude the role of PKC. Activation of $\mathrm{Ca}$ channels in isolated AM by $\mathrm{PKA}_{\mathrm{cs}}$ and in intact cells by $8-\mathrm{Br}-$ cAMP suggest that this enzyme system potentially mediates the stimulatory effects of PTH and cAMP on $\left[\mathrm{Ca}^{2+}\right]_{i}$ and on lumen-to-bath $\mathrm{Ca}$ transport. It must however be emphasized that these implications do not necessarily establish the role of apical $\mathrm{Ca}$ channel in $\mathrm{Ca}$ absorption or exclude other functions (see below).

Fourth, nifedipine suppression despite prior and continued exposure to PKA $\mathrm{A}_{\mathrm{cs}}$ and ATP suggests that the phosphorylated substrate(s) or protein(s) must be integral in the membrane and associated with the dihydropyridine-binding site, analogous to excitable cells L-type Ca channels $(14,15)$. The cooperativity between $\mathrm{PKA}_{\mathrm{cs}}$ and Bay K 8644 in stimulating $P_{\mathrm{o}}$ reinforces this notion.

Fifth, with full control and definition of the electrochemical milieu on both sides of the membrane, it can be inferred that the effects of $\mathrm{PKA}_{\mathrm{cs}}$ are electrogenic and independent of $\left[\mathrm{Na}^{+}\right]$ or $\left[\mathrm{H}^{+}\right]$gradients, which are typical of $\mathrm{Ca}: \mathrm{Na}$ or $\mathrm{Ca}: \mathrm{H}$ antiporters. Channel conductance and $E_{\text {rev }}$ are essentially unaltered by $20 \mathrm{mM}$ bath $\mathrm{Na}$ and pipette amiloride. The high $\mathrm{Ca} /$ $\mathrm{Na}$ permeability ratio argues against a nonspecific cation channel.

Sixth, the AM Ca flux rate ( $\mathrm{pmol} / \mathrm{mm}$ per $\min$ ) can be calculated by Ca current - tubule luminal surface area/patched area $\cdot$ channel incidence $\cdot$ channels $n$ per patch $\cdot P_{\mathrm{o}} /$ Faraday constant. Given the measured mean lumen i.d. of $30 \mu \mathrm{m}, 2.3$ channels per $1 \mu \mathrm{m}$ patch diameter, $2.57 \%$ for $P_{\mathrm{o}}$, and $5.18 \mathrm{pA}$ for peak current at resting $V_{\mathrm{m}}$, estimates yield a transmembrane Ca flux rate of $6.9 \mathrm{pmol} / \mathrm{mm}$ per min. This is comparable to the net transepithelial $\mathrm{Ca}$ absorption rates recently reported for microperfused CNT after treatment with cAMP ( $5.83 \pm 0.37)$, or with 0.1 or $1.0 \mathrm{nM}$ of synthetic PTH-(1-34) $(3.93 \pm 0.79$ or $9.44 \pm 1.13 \mathrm{pmol} / \mathrm{mm}$ per min, respectively) (2). With a slower perfusion rate $(2.4 \mathrm{vs} .6 .5 \mathrm{nl} / \mathrm{min})$ and a lower perfusate $\left[\mathrm{Ca}^{2+}\right]$ ( 1 vs. $\left.1.8 \mathrm{mM}\right)$, a smaller rate $(1.08 \pm 0.26 \mathrm{pmol} / \mathrm{mm}$ per $\mathrm{min})$ was found by Shareghi and Stoner (17), despite treatment with $30 \mathrm{mU} / \mathrm{ml}$ of PTH extracts. Before PTH, the basal rate $(0.38 \mathrm{pmol} / \mathrm{mm}$ per min $)$ was also lower in their hands (17), which is compatible with the lower flux rate of $0.31 \mathrm{pmol} / \mathrm{mm}$ per min we calculated from the spontaneous $P_{\mathrm{o}}$ of $0.052 \%$.

We must emphasize the inherent uncertainties and potential errors associated with the above correlation attempt. There are many differences in experimental conditions, preparations, techniques, and methodologies, as well as many unproven assumptions involved in the estimates. For example, our patchclamp studies were performed, by necessity, with $50 \mathrm{mM} \mathrm{Ba}^{2+}$, whereas most tubule perfusion experiments employed 1-2 mM perfusate [Ca]. Thus, the deduced transmembrane $\mathrm{Ca}$ flux could theoretically represent $20-50$ overestimate, although the impact of divalent cation concentration on current is not linear, with apparent dissociation constant of 14 and $28 \mathrm{mM}$ for $\mathrm{Ca}$ and $\mathrm{Ba}$ respectively (18). In practice, the effect of $50 \mathrm{mM}$ $\mathrm{Ba}^{++}$on current amplitude could be calculated to be 18.5 fold higher than that obtained with $1 \mathrm{mM}$ (18).

Relative to the $\mathrm{Ca}$ absorption rate reported by Shareghi and Stoner $(1.08 \pm 0.26 \mathrm{pmol} / \mathrm{mm}$ per $\mathrm{min})$, our transmembrane Ca flux estimate, after adjustment for the 18.5-fold increase due to high $\left[\mathrm{Ba}^{2+}\right](18)(0.37 \mathrm{pmol} / \mathrm{mm}$ per $\mathrm{min})$, is still 


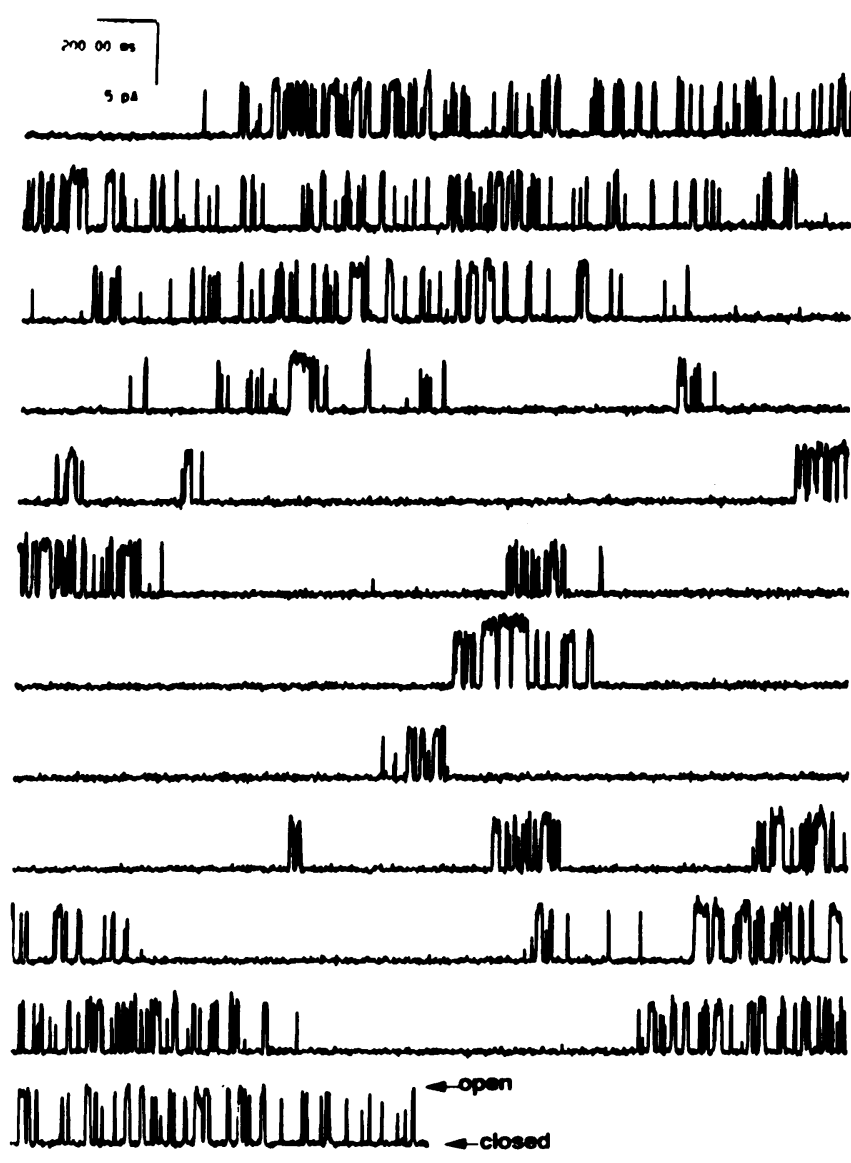

Figure 5. Single Ca channel recording from an excised, inside-out patch, activated by pipette and bath Bay $\mathrm{K}(50 \mu \mathrm{M})$; and by bath 1 $\mu \mathrm{g} / \mathrm{ml} \mathrm{PKA} \mathrm{css}_{\mathrm{cs}}$ and $2 \mathrm{mM} \mathrm{Mg} \mathrm{ATP.} \mathrm{Before} \mathrm{excision,} \mathrm{cell} \mathrm{was} \mathrm{incubated}$ with 8-Br-cAMP, $3.75 \mathrm{mM}$, for $27 \mathrm{~min}$. $V_{\mathrm{m}}=-70 \mathrm{mV}$. Closed, nonconductive state; open, conductive state showing unitary current.

somewhat lower. However, this might be the consequence of the room temperature condition of our experiment, which is known to depress Ca transport (19) and channel activity (20) as compared to $37-38^{\circ} \mathrm{C}$. In addition, transcellular Ca transport is modulated by other cytosolic events and BLM extrusion mechanisms $(2,21-23)$, contribution of which is not available in isolated apical membrane preparation. Given these inherent differences, some discrepancies from measurements obtained in intact tubules are likely, if not inevitable. Nevertheless, the above flux estimates must be viewed as speculative till more vigorous and systematic observations.

The current view that $\mathrm{Ca}$ diffuses across the AM down electrochemical gradients (24) may be open to questions, given the negligible spontaneous channel activity in most seals, despite a transmembrane potential gradient of $-70 \mathrm{mV}$ and chemical concentration difference of $50 \mathrm{mM}$. Passive $\mathrm{Ca}$ influx was absent until $\mathrm{PKA}_{\mathrm{cs}}$ was introduced, consistent with the proposed notion of a regulated $\mathrm{Ca}$ influx pathway.

The precise function of apical $\mathrm{Ca}$ channels identified here is presently undefined. We speculate a role in transcellular $\mathrm{Ca}$ transport, because in the CNT, PTH and cAMP are known to not only stimulate $\mathrm{Ca}$ absorption $(1,2,17,22)$ but also enhance apical membrane $\mathrm{Ca}$ influx from across the lumen $(3,4$, 6 ). The presently documented PKA $\mathrm{Ass}_{\mathrm{c}}$-activated AM Ca channel would provide a potential membrane mechanism for the physiologic function of the PTH and its putative second mes-

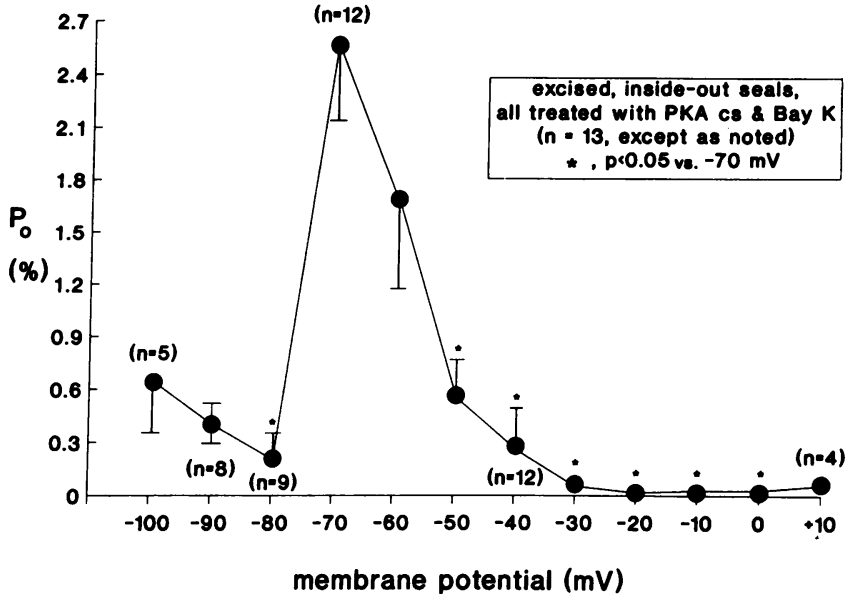

Figure 6. $P_{\mathrm{o}}$ data (mean $\pm \mathrm{SE}$ ) are plotted as a function of $V_{\mathrm{m}}$ from 14 excised, inside-out patches. Before excision, 10 were treated with 8Br-cAMP $(2.7 \pm 0.4 \mathrm{mM})$ for $36 \pm 9 \mathrm{~min}$. Nine were exposed to pipette Bay $\mathrm{K}(43 \pm 4 \mu \mathrm{M})$. After excision, all seals were exposed to bath BAY $\mathrm{K}(37 \pm 5 \mu \mathrm{M}), \mathrm{PKA}_{\mathrm{cs}}(1 \mu \mathrm{g} / \mathrm{ml})$, and $\mathrm{Mg} \operatorname{ATP}(2 \mathrm{mM})$. At extreme $V_{\mathrm{m}}$, stable $\mathrm{G} \Omega$ seals were not always possible, reducing the number of observations.

senger. The CNT is the most important rabbit nephron segment in regulating final urine $\mathrm{Ca}(23,24)$, due to its unique sensitivity to $10^{-10} \mathrm{M}$ PTH $(2,3,4)$, thiazide, amiloride (22, 25 ), and lumen $\mathrm{Na}$ depletion $(21,22)$, features not shared by other nephron segments.

However, other roles must be considered. For example, future experiments performed at $38^{\circ} \mathrm{C}$ may reveal no significant stimulation of $P_{\mathrm{o}}$ by any known agonists to approximate the in vitro $\mathrm{Ca}$ absorption rate. There is increasing evidence to support the concept that $\mathrm{Ca}$ transients can serve to activate renal epithelial cell processes (26-28). For instance, increases in cy-

\section{Current (pA)}

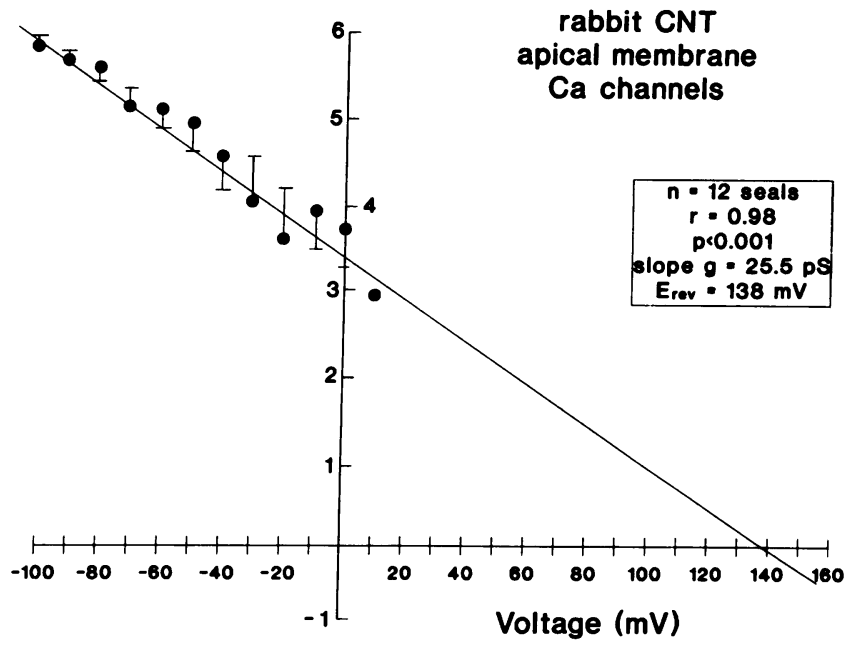

Figure 7. Current-voltage curve from 12 excised, inside-out patches. Current data are presented as mean $\pm \mathrm{SE}$. Before excision, eight were exposed to 8-Br-cAMP (1-3.75 mM). After excision, all were bathed by $\operatorname{PKA}_{\mathrm{cs}}(1 \mu \mathrm{g} / \mathrm{ml})$, and $\mathrm{Mg} \operatorname{ATP}(2 \mathrm{mM})$. Bay $\mathrm{K}(5-50 \mu \mathrm{M})$, was present in the pipette $(n=3)$, bath $(n=6)$, or both $(n=1)$. 
Before Nifedipine

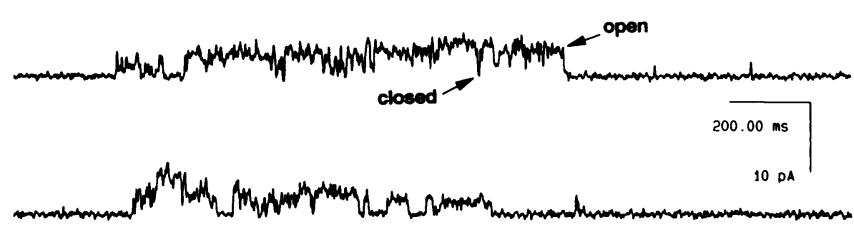

During Nifedipine

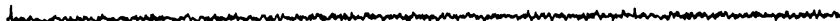

mathon

Figure 8. Effect of nifedipine on Ca channel activity in an excised, inside-out patch treated with bath $1 \mu \mathrm{g} / \mathrm{ml} \mathrm{PKA}_{\mathrm{cs}}, 2 \mathrm{mM} \mathrm{Mg} \mathrm{ATP \text {, }}$ and $<0.05 \%$ DMSO. Pipette contained $18.5 \mu \mathrm{M}$ Bay K throughout. Upper two tracings were obtained before nifedipine, when bath contained $18.5 \mu \mathrm{M}$ Bay K 8644. Lower two tracings were obtained during nifedipine when bath Bay $\mathrm{K} 8644$ was replaced by $25 \mu \mathrm{M}$ of nifedipine. $V_{\mathrm{m}}=-50 \mathrm{mV}$. These recordings are representative of three similar seals.

tosolic $\left[\mathrm{Ca}^{2+}\right]$ have been found to stimulate distal nephron AM $\mathrm{K}$ channels $(26,27)$ and to inhibit AM Na channels $(28)$. Interestingly, PTH and cAMP elicit biphasic changes in CNT AM potential, consistent with the proposal of a dual modulation of AM Na channels (29): a direct stimulation by cAMP, but an indirect inhibition via the known increases in cytosolic $\left[\mathrm{Ca}^{2+}\right]$ secondary to PTH or cAMP $(3,4)$. Specific studies will be needed to directly test these mutually nonexclusive hypotheses.

We did not focus on cell-attached patches for several reasons. One, $V_{\mathrm{m}}$ cannot be precisely controlled. $\mathrm{Ba}$, amiloride, PTH, and cAMP are known to alter $V_{\mathrm{m}}(10,29)$. Two, cytoplasmic (ions) and enzyme compositions could not be measured or controlled, rendering uncertain any estimates on $E_{\mathrm{eq}}$. Three, the ease, certainty, and timing of completely delivering and/or withdrawing agonists/antagonists are better achieved in cell-free membrane patches. Finally, in our hands, on-cell patches are less stable than excised patches, especially during prolonged superfusion.

In summary, our results provide the first direct evidence for Ca channels in connecting tubule cells, consistent with the hypothesis of a possible functional role in transepithelial Ca transport. The properties, regulation, and function of these channels are yet to be defined.

\section{Acknowledgments}

We gratefully acknowledge the invaluable technical advice by Dr. James Bourdeau, Larry Palmer, and Gustavo Frindt. We appreciate the technical assistance of Bonnie Eby. Special thanks are due to Dr. Patrick McKee for his encouragement, to the Oklahoma Center of Molecular Medicine for facility and site supports, and to Meg Schmidt for secretarial assistance.

The work was supported by National Institute of Diabetes and Digestive and Kidney Diseases grant DK-33507 and an award for project number HR3-072 from the Oklahoma Center for the Advancement of Science and Technology.

\section{References}

1. Imai, M. 1981. Effects of parathyroid hormone and $\mathrm{N}^{6}, \mathrm{O}^{2}$-dibutyryl cyclic AMP on $\mathrm{Ca}^{2+}$ transport across the rabbit distal nephron segments perfused in vitro. Pflügers Arch. Eur. J. Physiol. 390:145-151.

2. Shimizu, T., K. Yoshitomi, M. Nakamura, and M. Imai. 1990. Effects of PTH, calcitonin, and cAMP on calcium transport in rabbit distal nephron segments. Am. J. Physiol. 259:F408-F414.

3. Bourdeau, J. E., and K. Lau. 1989. Effects of parathyroid hormone on cytosolic free calcium concentration in individual rabbit connecting tubules. $J$. Clin. Invest. 83:373-379.

4. Bourdeau, J. E., and B. K. Eby. 1990. cAMP-stimulated rise of $\left[\mathrm{Ca}^{2+}\right]_{\mathrm{i}}$ in rabbit connecting tubules: role of peritubular Ca. Am. J. Physiol. 258:F751F755.

5. Bacskai, B. J., and P. A. Friedman. 1990. Activation of latent $\mathrm{Ca}^{2+}$ channels in renal epithelial cells by parathyroid hormone. Nature (Lond.). 347:388-391.

6. Lau, K., and J. E. Bourdeau. 1989. Evidence for cAMP dependent protein kinase in mediating the parathyroid hormone stimulated rise in cytosolic free calcium in rabbit connecting tubules. J. Biol. Chem. 264:4028-4032.

7. Palmer, L. G., and G. Frindt. 1986. Amiloride-sensitive Na channels from the apical membrane of the rat cortical collecting tubule. Proc. Natl. Acad. Sci. USA. 83:2767-2770.

8. Wang, W., A. Schwab, and G. Giebisch. 1990. Regulation of small-conductance $\mathrm{K}^{+}$channel in apical membrane of rat cortical collecting tubule. Am. J. Physiol. 259:F494-F502.

9. Snedecor, G. W., and W. G. Cochran. 1967. Statistical Methods, 6th edition. Iowa State University Press, Ames, IA. 593 pp.

10. Yoshitomi, K., Shimizu, T., Taniguchi, J., and Imai, M. 1989. Electrophysiological characterization of rabbit distal convoluted tubule cell. Pflügers Arch. Eur. J. Physiol. 414:457-463.

11. Muto, S., K. Yasoshima, K. Yoshitomi, M. Imai, and Y. Asano. 1990. Electrophysiological identification of $\alpha$ - and $\beta$-intercalated cells and their distribution along the rabbit distal nephron segments. J. Clin. Invest. 86:1829-1839.

12. Pelzer, D., S. Pelzer, and T. F. McDonald. 1990. Properties and regulation of calcium channels in muscle cells. Rev. Physiol. Biochem. Pharmacol. 114:108207.

13. Fox, A. P., M. C. Nowycky, and R. W. Tsien. 1987. Single-channel recordings of three types of calcium channels in chick sensory neurons. J. Physiol. (Lond.). 394:173-200

14. Armstrong, D., and R. Eckert. 1987. Voltage-activated calcium channels that must be phosphorylated to respond to membrane depolarization. Proc. Natl. Acad. Sci. USA. 84:2518-2522.

15. Nunoki, K., V. Florio, and W. A. Catterall. 1989. Activation of purified calcium channels by stoichiometric protein phosphorylation. Proc. Natl. Acad. Sci. USA. 86:6816-6820.

16. Hruska, K. A., D. Moskowitz, P. Esbrit, R. Civitelli, S. Westbrook, and M. Huskey. 1987. Stimulation of inositol triphosphate and diacylglycerol production in renal tubular cells by parathyroid hormone. J. Clin. Invest. 79:230-239.

17. Shareghi, G. R., and L. C. Stoner. 1981. Calcium transport across segments of the rabbit distal nephron in vitro. Am. J. Physiol. 235:F367-F375.

18. Hess, P., J. B. Lansman, and R. W. Tsien. 1986. Calcium channel selectivity for divalent and monovalent cations. J. Gen. Physiol. 88:293-319.

19. Rouse, D., RCK Ng, and W. K. Suki. 1980. Calcium transport in the pars recta and thin descending limb of Henle of the rabbit, perfused in vitro. J. Clin. Invest. 65:37-42.

20. Lacerda, A. E., and A. Brown. 1989. Nonmodal gating of cardiac calcium channels as revealed by dihydropyridines. J. Gen. Physiol. 93:1243-1273.

21. Bourdeau, J. E., and K. Lau. 1990. Basolateral cell membrane Ca-Na exchange in single rabbit connecting tubules. Am. J. Physiol. 258:F1497-F1503.

22. Shimizu, T., M. Nakamura, K. Yoshitomi, and M. Imai. 1991. Interaction of trichlormethiazide or amiloride with PTH in stimulating $\mathrm{Ca}^{2+}$ absorption in rabbit CNT. Am. J. Physiol. 261:F36-F43.

23. Bourdeau, J. E., and K. Lau. 1992. Regulation of cytosolic free calcium concentration in the rabbit connecting tubule: a calcium-absorbing renal epithelium. J. Lab. Clin. Med. 119:650-662.

24. Rouse, D., and W. N. Suki. 1990. Renal control of extracellular calcium. Kid. Int. 38:700-708.

25. Shimizu, T., K. Yoshitomi, M. Nakamura, and M. Imai. 1988. Site and mechanism of action of trichlormethiazide in rabbit distal nephron segments perfused in vitro. J. Clin. Invest. 82:721-730.

26. Tan, S., and K. Lau. 1991. Regulation of potassium channel in apical membranes of rabbit connecting tubule by cytoplasmic $\mathrm{Ca}^{2+}$ and $\mathrm{H}^{+}$(Abstract). J. Am. Soc. Nephrol. 2:752.

27. Frindt, G., and L. G. Palmer. 1987. Ca-activated K channels in apical membrane of mammalian CCT, and their role in K secretion. Am. J. Physiol. 252:F458-F467.

28. Palmer, L. G., and G. Frindt. 1987. Effects of cell $\mathrm{Ca}$ and $\mathrm{pH}$ on $\mathrm{Na}$ channels from rat cortical collecting tubule. Am. J. Physiol. 253:F333-F339.

29. Shimizu, T., K. Yoshitomi, M. Nakamura, and M. Imai. 1990. Effect of parathyroid hormone on the connecting tubule from the rabbit kidney; biphasic response of transmural voltage. Pflügers Arch. Eur. J. Physiol. 416:254-261. 